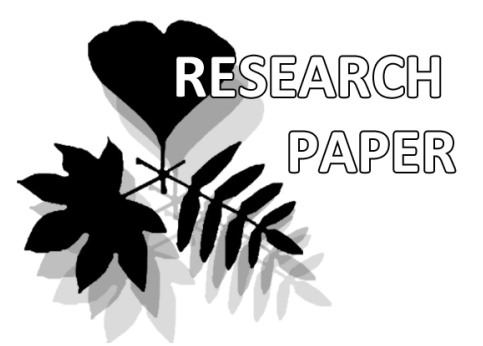

\title{
On Small Pinnate Leaves of Peltasperm Pteridosperms from the Early Triassic of the Kuznetsk Basin (Mal'tsevo Formation, Babii Kamen Locality)
}

\author{
Evgeny Karasev
}

Evgeny Karasev

e-mail: karasev@paleo.ru

A.A. Borissiak Paleontological Institute, Russian Academy of Sciences, Moscow 117647 Russia

Manuscript received: 20.08 .2015

Review completed: 20.10.2015

Accepted for publication: 22.10.2015

Published online: 25.10.2015

\begin{abstract}
A B S T R A C T
The Babii Kamen flora is one of the most important Early Triassic floras of the Kuznetsk Basin. New data about the floristic assemblage were obtained from the Babii Kamen locality of Mal'tsevo formation. Fragments of fronds were found with very small pinnae and tiny pinnules. The general morphology of these leaves and specific epidermal-cuticular characters show their undeniable affinity to the peltasperm Lepidopteris arctica Mogutcheva, 1980. Leaves of L. arctica were first described from the Lower Triassic locality of Cape Tsvetkov, East Taimyr. The presence of leaves of L. arctica from the Babii Kamen locality confirms the correlation of the deposits of the Mal'tsevo formation with sections of Induan (or Late Permian?) age of the East Taimyr.
\end{abstract}

K e y w o r d s : paleobotany, Lepidopteris, peltasperms, Kuznetsk Basin, Early Triassic

\section{P E 3 Ю M E}

Карасев Е. О мелких перистых мистьях пелтаспермовых семенных папоротников из раннего триаса Кузнецкого бассейна (мамьцевская свита, разрез Бабий Камень). ФАора Бабьего Камня - одна из кАючевых раннетриасовых флор Кузнецкого бассейна. Получены новые Аанные о составе флоры отложений мальцевской свиты разреза Бабьего Камня. В

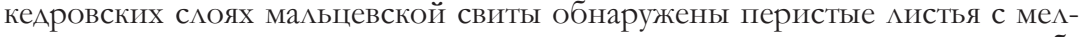
кими перышками, которые после изучения эпидермального строения и общей морфологии мистьев отнесены к пельтаспермовым птеридоспермам Lepidopteris arctica Mogutcheva, 1980. Впервые мистья L. arctica были описаны из нижнего триаса местонахождения мыс Цветков Восточного Таймыра. Находка Lepidopteris arctica подтверждает корреляцию отложений мальцевской свиты с инАскими (или позАнепермскими?) отложениями Восточного Таймыра.

К $\mathbf{\Lambda}$ ю че в ы е ск ов а : палеоботаника, Lepidopteris, пельтаспермовые птеридоспермы, Кузнецкий Бассейн, ранний триас

\section{INTRODUCTION}

Global changes in plant communities in the context of biosphere crises always were within the interests of Valentin Krassilov. He launched studies of Permian-Triassic plant ecosystems at the Paleontological Institute just before I began training in postgraduate study in laboratory of paleobotany. In 2005-2009, we continued to study floristic assemblages of terminal Permian deposits of the Moscow syneclise. Elucidation of global changes in plant communities at the Siberian platform was one of our aims.

The Babii Kamen locality is the most famous and one of the most complete sections of the Mal'tsevo Formation in the Kuznetsk Basin. In 1939, Belousova and Radchenko divided the Mal'tsevo formation into Tarakanihinsky, Barsuchiy, Kedrovsky and Ryabokamensky biostratigraphical horizons (Vladimirovich et al. 1967).

Deposits of the Mal'tsevo Formation lie on Tatarian deposits of the Tailuganskaya formation with a hidden nonconformity. Later, these horizons are transferred to the rank of "beds with flora" (Vladimirovich 1967). Resolutions of Interdepartmental Regional Stratigraphical Committee of Mesozoic and Cenozoic of Siberia accepted them as subformations of the Mal'tsevo formation (Anonymous 1981). The age of the deposits of the Mal'tsevo formation is still debated. Sadovnikov (1981) offers to include the Mal'tsevo formation to the terminal Permian based on the correlation of the Babii Kamen flora with so-called "Korvunchan” flora of Tunguska Basin. Goman'kov (2005) accepted this view. Betechtina et al. (1986) and Mogutcheva \& Krugovykh (2009) insist on the Early Triassic age of the Mal'tsevo Formation, because they believe that those deposits of the Tunguska Basin should be dated to the Early Triassic rather than to the terminal Permian.

The floristic assemblages of the Babii Kamen locality are among the richest assemblages on the Siberian platform. Since the beginning of the 20th century, many paleobotanists studied the flora of the Babii Kamen. Neuburg (1936) was the first who initiated layer-by-layer stratigraphy and paleobotany description of the section. Radczenko (1936), Vladimirovich $(1967,1980,1981)$, Srebrodolskaya (1960), Meyen (1981) and Mogutcheva (1984) have made significant contributions to our knowledge of the morphology and taxonomic diversity of the plants. 
Currently, the flora of Babii Kamen is represented by 26 genera and 36 species. Fern remains are a significant part of the plant diversity ( $50 \%$ of the total number of taxa); other groups of plants are conifers, cycadophytes, horsetails, and lycopsids.

Each beds with the flora (subformations) of the Mal'tsevo formation have characteristic features of the floristic composition, despite the fact that the thickness of the beds in Babii Kamen section varies in publications (Vladimirovich 1967, Radczenko 1973). Microsporophylls, leaves, and fragmentary shoots of lycopsids of the genus Tomiostrobus were found only in the basal part of the Tarakanikha beds. In addition to remains of Tomiostrobus, only fragments of pinnae and dispersed pinnules of Pecopteris were rarely found in this part of subformation. Upward the section, remains of Tomiostrobus are not found, and the floristic composition resembles that of Tarakanikha beds. The upper part of Tarakanikha beds and main part of Barsuchiya beds are characterized by the predominance of fern genera Cladophlebis, Katasiopteris, Pecopteris, Tungusopteris, and Todites, rare leaves and shoots of horsetails Paracalamites, Schizoneura and Neokoretrophyllites, leaves of pteridosperms Tersiella, cycadophytes Tomia and ginkgophyte Rhipidopsis. The Kedrovka beds are very different from the Tarakanikha and Barsuchya beds, which are dominated by the remains of numerous shoots of the conifer Quadrocladus, while remains of ferns Cladophlebis, Katasiopteris, Kedroviella and Kchonomakidium occupy a subordinate position and leaves of Neokoretrophyllites occur even more rarely. Leaves of peltaspermacean pteridosperm Lepidopteris arctica Mogutcheva, 1980 were found in the lower and middle parts of Kedrovka beds.

\section{MATERIAL AND METHODS}

In 2013, about 200 plant megafossils have been discovered in the deposits of Mal'tsevo formation of the Babii Kamen section by a field-team of scientists of the Paleontological Institute and students of Moscow State University. The section is located at the right bank of the Tom' River, $10 \mathrm{~km}$ downstream of the village of Ust' Naryk, Novokuznetsk District, Kemerovo Region (Fig. 1). The plant remains are preserved as impressions and compressions. The compressions were macerated using the standard technique: treated first with nitric acid, washed in water and then treated with $\mathrm{KOH}$. The leaves were studied with a Leica M165 stereomicroscope in reflected light. Cuticles were analyzed in transmitted light with an AXIOPLAN-2 microscope equipped with a Leica DFC420 digital camera. The macro photos of leaves were made with a Nikon d60 digital camera. The material is kept at the A.A. Borissiak Paleontological institute of the Russian Academy of Sciences, no. PIN 5542.

\section{E S C R I P T I O N \\ Lepidopteris Schimper 1869}

\section{Lepidopteris arctica Mogutcheva, 1980; Figures 2-3}

Description. The collection includes 10 fragments of small pinnate leaves. Fronds are bipinnate at least. The pinnae are suboppositely or alternately attached and diverge from rachis at an angle 66-80 degrees (Fig. 2A, B). Pinnae of the last order are $5-10 \mathrm{~mm}$ long and $1.5-5 \mathrm{~mm}$ wide (Fig. 2C, D). Pinnules are small, alethopteroid, and entiremargined, with an obtuse-rounded apex and decurrent base; occasionally, the pinnules can be fused to more than two-thirds of their length. Pinnules are 1.2-1.8 $\mathrm{mm}$ long and $0.6-0.9 \mathrm{~mm}$ wide, with an angle of divergence about $55-65^{\circ}$. The venation of pinnules is obscured by the thick cuticle (Fig. 2E).

The fronds are amphistomatic with a thinner cuticle with more numerous stomata on the lower surface (Fig. 3 A-E). The epidermal cells are rectangular or polygonal, longitudinally elongated (Fig. 3B). The stomata are monocyclic, sunken and irregularly scattered. The papillae are present on ordinary and subsidiary epidermal cells. The stomatal pit is protected by the overarching papillae of 5-6 (rarely 7) trapezoid subsidiary cells (Fig. 3C, F). The unicellular trichomes were observed on the upper surface (Fig. 3C). Guard cells are weakly cutinized, elongated with distinct stomatal ledges.

Comments. The fragmentary fronds found in the Babii Kamen have enough similarities to leaves of L. arctica from the Induan deposits of the Tsvetkovo locality of East Taimyr (Mogutcheva 1980) to be determined as L. arctica.

The described fragments of fronds have much common features in the morphology and epidermal structure with leaves of Germaropteris (Lepidopteris) martinsii from Upper

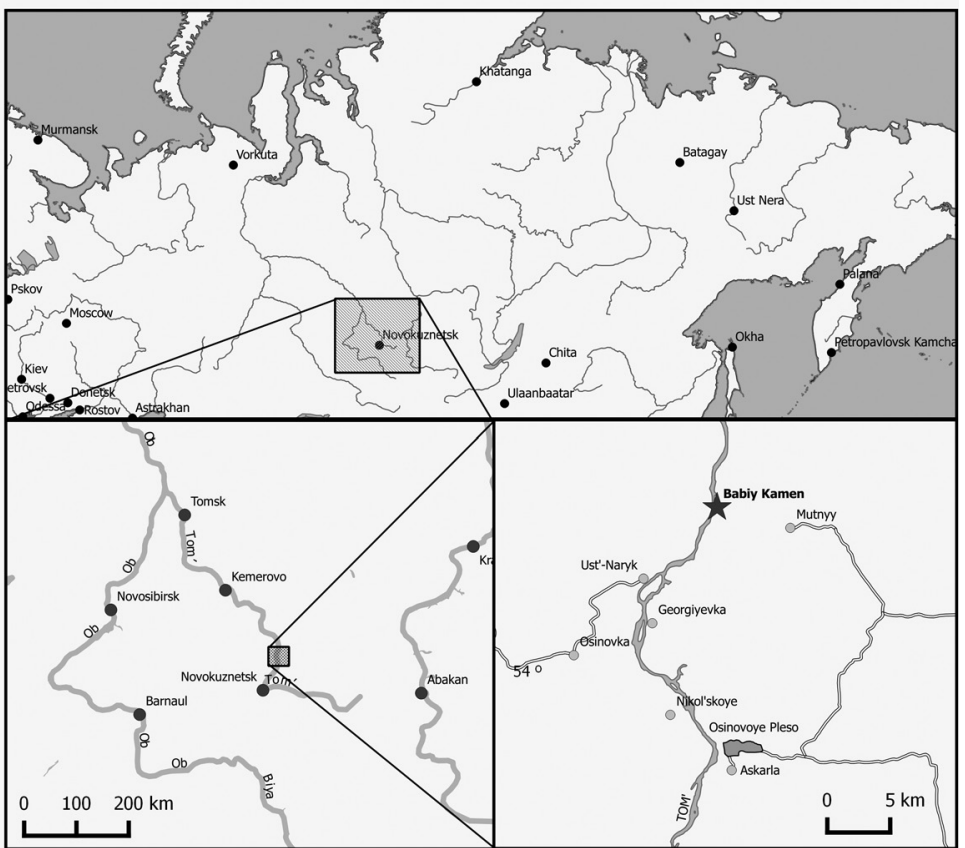

Figure 1 Geographic position of the Babii Kamen locality 

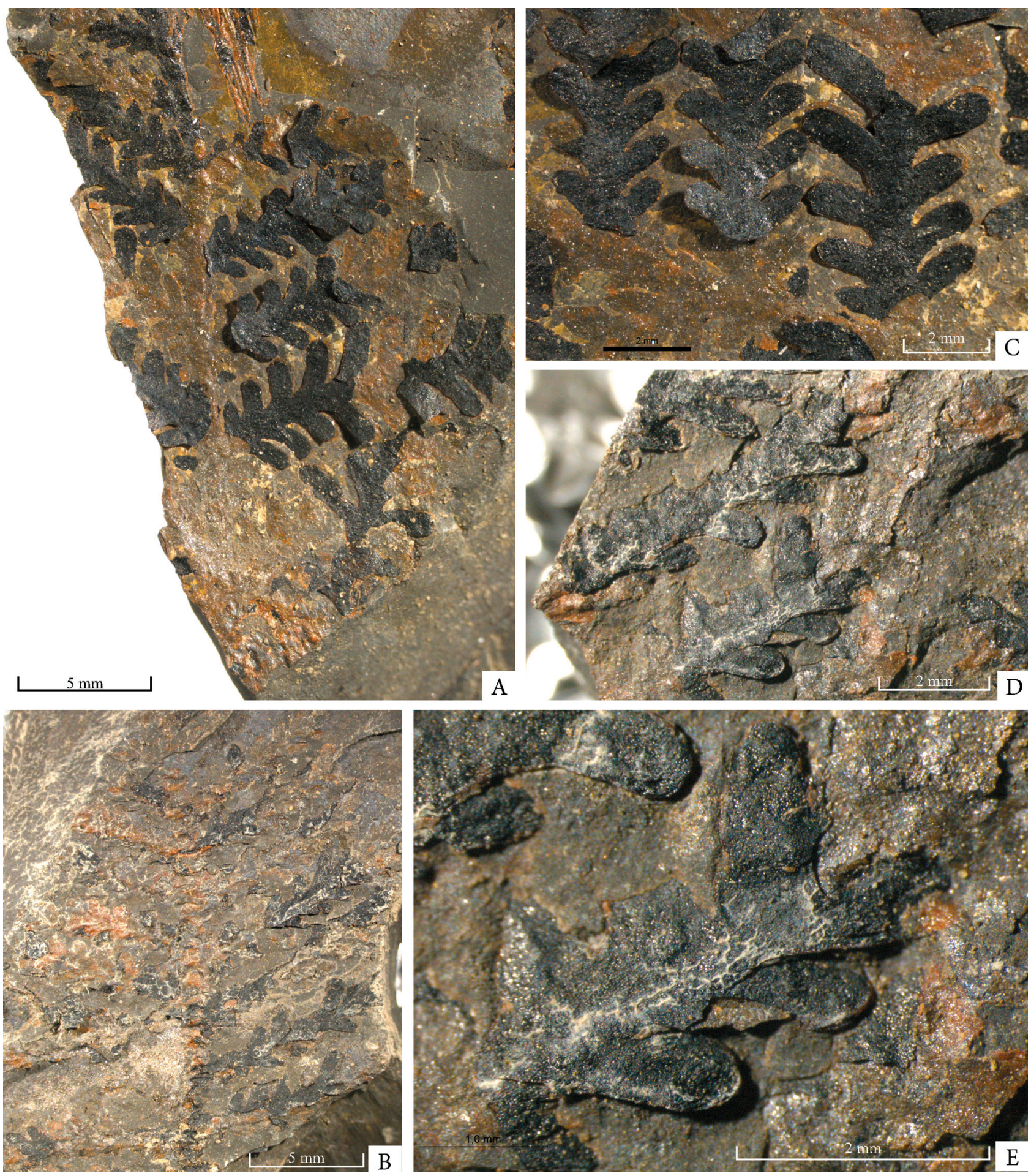

Figure 2 Lepidopteris artica Mogutcheva, 1980, LM, Babii Kamen locality, Kemerovo region, Kuznetsk basin: A, B - general view of fragmentary fronds; C, D, E - morphology of pinnae. Specimens: A, C - PIN № 5542/17; B, D, E - PIN № 5542/18

and Early Triassic sediments of Western Europe, leaves of Permophyllocladus polymorphus from the Russian platform, and Lepidopteris baodensis from the Late Permian in North China. Leaves of Lepidopteris arctica from the Babii Kamen locality are different from all of these species by well-developed pinnules and weak subepidermal swellings ("blisters").

Vladimirovich (1980) described from Tarakaniha beds pinnate leaves of Cladophlebis pusilla Vladimirovich, which are similar in size and some morphological features to the leaves under description. The leaves of Cladophlebis pusilla differ from those of Lepidopteris arctica by the morphology of the pinnae rachis, pecopteroid type, and distinct venation of pinnules. Apparently, leaves of C. pusilla should be attributed to ferns on the basis of the typical morphology of the pinnae rachis, well defined venation of pinnules and thin cuticle.

Distribution. East coast of Taimyr, Tsvetkov Cape, lower terrigenous beds of Induan age (Mogutcheva 1980). The Babii Kamen locality, Kemerovo region, Kuznetsk Basin, Kedrovka beds of Maltsevo formation, Lower Triassic. 

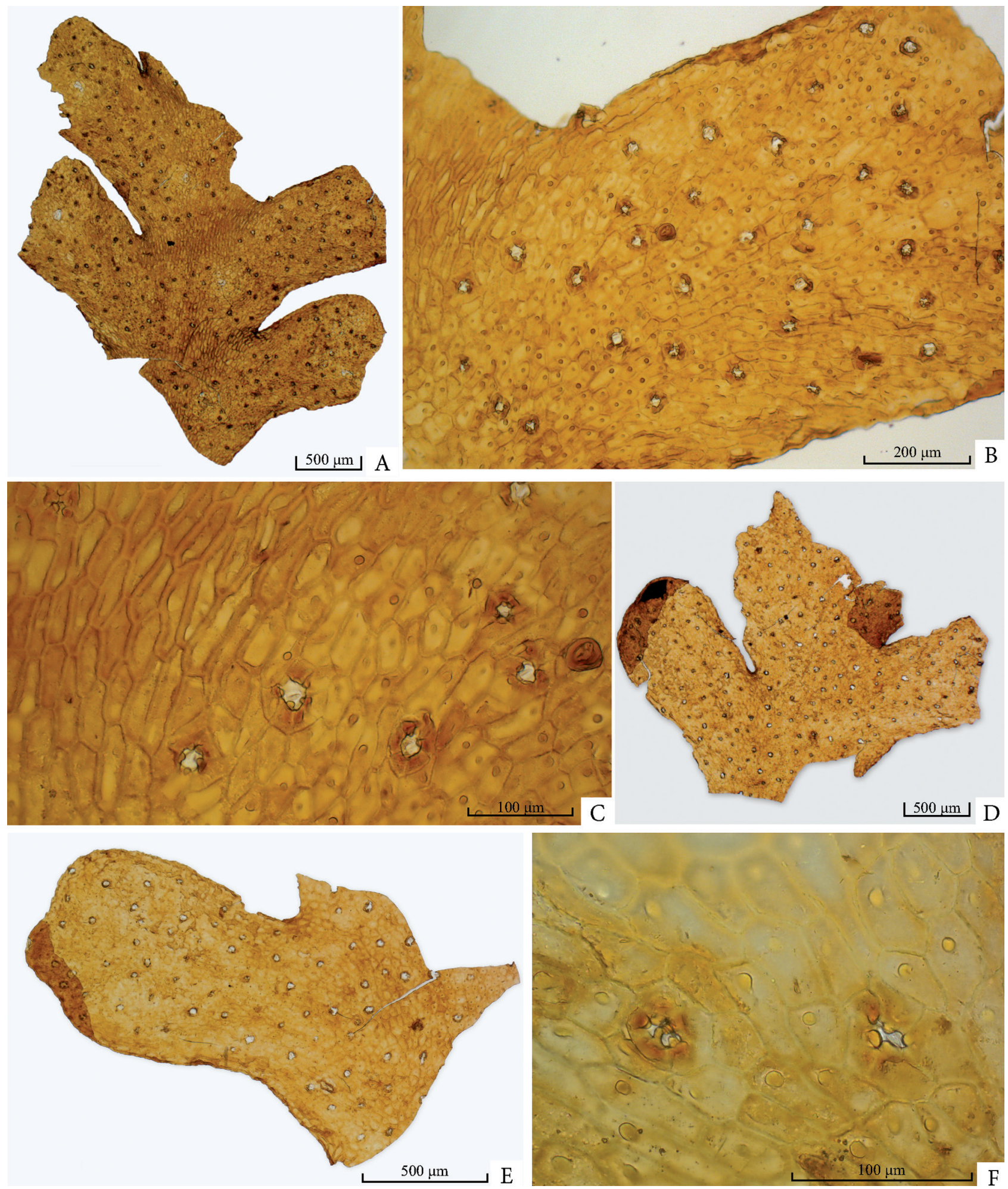

Figure 3 Lepidopteris artica Mogutcheva, 1980, LM, Babii Kamen locality, Kemerovo region, Kuznetsk basin, PIN № 5542/17: A, B, C cuticle of the lower epidermis, note hair-like structures on epidermal cells; D, E, F - cuticle of the upper epidermis

Specimens examined: ten specimens, no. PIN \# $5542 / 17-20,22,23,74-77$.

\section{DISCUSSION}

Pteridosperm remains in the Babii Kamen are represented by leaves of two types. These are linear-lanceolate leaves of Pursongia (Tersiella) beloussovae (Radczenko \& Srebrodolskaya 1960) Meyen and Gomankov 1980 and small fronds of Lepidopteris arctica Mogutcheva, 1980. Meyen (1981) compared P. (T.) beloussovae with leaves of the genus Tatarina from of the Late Permian and Induan of "Subangara» flora. Leaves of Tatarina are widespread in the Russian Platform, starting from the top of the Severodvinian age. Shoots of the conifer genus Quadrocladus are one more element of "Subangara" flora (Meyen 1981). However, it should be noted that the epidermal structure of 
P. (T.) beloussovae remains unknown, that does not exclude a close relationship with other plants with linear-lanceolate leaves which have a similar morphology, such as Kirjamkenia, Maria, etc. As far as generative structures of Sashinia associated with Quadrocladus leaves are not found in the Babii Kamen locality, it is premature to relate these leaves to the family Sashiniaceae Gomankov 2010. Recently, a different type of male generative structure was found in organic connection with leaves of Quadrocladus from the upper part of Severodvinian age of the Moscow syneclise of the Isady (=Mutovino) locality of Vologda region (Karasev, in preparation).

The stratigraphic range of most species of Lepidopteris is limited to the Triassic. For a long time, only one species, L. martinsii, was known from the Permian deposits. L. martinsii was found at many Late Permian localities of the Northern Hemisphere (Townrow 1960, Poort \& Kerp 1990). Kustatscher et al. (2014) showed that leaves of L. martinsii are strongly different from all other species of this genus and, therefore, they erected the new genus Germaropteris for such leaves.

Some species from the Permian and Triassic deposits show similar features to Germaropteris (Lepidopteris) martinsii (Germar) Townrow. Thus, leaves of L. arctica from the Lower Triassic deposits of the Eastern Taymyr have similar morphology and epidermal features (Mogutcheva 1980). The similar morphology was observed in pinnae with little pinnules described as $L$. archaica from Lopingnian deposits of Russian platform (Gomankov 2006) and from contemporary deposits as Lepidopteris baodensis from the North China (Zhang et al. 2012). Leaves that are very similar to G. (L.) martinsii were found in the Latest Permian deposits of the Sokovka locality near Vyazniki city and described as Permophyllocladus polymorphus (Karasev \& Krassilov 2007). Thus, Germaropteris-like leaves were wide spread in the Lopingian and Lower Triassic sediments on the territory of the northern hemisphere.

The presence of leaves of peltasperms $L$. arctica in the Kedrovka bed allows one to confidently compare the flora of the Babii Kamen locality with the Lower Triassic flora of East Taimyr, where remains of Tomiostrobus and Quadrocladus also were found (Mogutcheva 1980, Mogutcheva \& Krugovykh 2009).

\section{ACKNOWLEDGEMENTS}

I am sincerely grateful to N.E. Zavialova (Borissiak Paleontological Institute of the Russian Academy of Sciences, Moscow) for linguistic corrections. This work was supported by the Russian Foundation for Basic Research, grant no. 15-34-20745.

\section{LITERAT URE CITED}

Anonymous 1981. Resolutions of the 3rd Interdepartmental Regional Stratigraphic Conference on Mesozoic and Cenozoic of Central Siberia. CNIIGGIMS, Novosibirsk, 91 pp. (in Russian). [Решения 3-го Межведомственного регионального стратиграфического совещания по мезозою и кайнозою Средней Сибири. Новосибирск: СНИИГГиМС, 1981. 91 с.].

Betechtina, O.A., N.K. Mogutcheva, S.K. Batyaeva \& M.P. Ku- shnarev 1986. Permian-Triassic boundary in the stratotype of the Maltsevo Formation of Kuzbass. In: Biostratigraphy of the Mesozoic of Siberia and Far East (A.V. Golbert, ed.), pp. 31-38, Nauka, Novosibirsk (in Russian). [Бетехтина O.A., Могучева Н.К., Батяева С.К., Кушнарев М.П. 1986. Граница перми и триаса в стратотипе мальцевской свиты Кузбасса // Биостратиграфия мезозоя Сибири и Аальнего Востока. Новосибирск: Наука. С. 31-38].

Gomankov, A.V. 2005. Floral changes across the PermianTriassic boundary. Stratigraphy and Geological Correlation 13(2):74-83.

Gomankov, A.V. 2006. A new species of the genus Lepidopteris (Peltaspermaceae, Peltaspermales) from the Upper Permian of the Russian Platform. Botanicheskii Zhurnal 91(12):19061914 (in Russian). ГГоманьков А.В. 2006. Новый виА рода Lepidopteris (Peltaspermaceae, Peltaspermales) из верхнепермских отложений русской платформы // Ботанический журнал, Т. 91, № 12. С. 1906-1914].

Gomankov, A.V. 2010. Conifers from the Permian of the Kargala mines (Southern ForeUrals). Paleobotanika 1:5-21 (in Russian). [Гоманьков А.В. 2010. Хвойные из пермских отложений Каргалинских рудников (Южное Приуралье) // Палеоботаника. Т. 1. С. 5-21].

Karasev, E.V. \& V.A. Krassilov 2007. Late Permian phylloclades of the new genus Permophyllocladus and problems of the evolutionary morphology of peltasperms. Paleontological Journal 41(2):198-206.

Kustatscher, E., K. Bauer, R. Butzmann, T.C. Fischer, B. Meller, J. H. A. Van Konijnenburg-van Cittert \& H. Kerp. 2014. Sphenophytes, pteridosperms and possible cycads from the Wuchiapingian (Lopingian, Permian) of Bletterbach (Dolomites, Northern Italy). Review of Palaeobotany and Palynology 208:65-82.

Meyen, S.V. 1981. Some true and alleged Permotriassic conifers of Siberia and the Russian Platform and their alliance. Palaeobotanist 28/29:161-176.

Meyen, S.V. \& A.V. Gomankov 1980. Peltasperm pteridosperms of the genus Tatarina. Paleontologicheskii Zhurnal 2:116-132 (in Russian). [Мейен С.В., Гоманьков А.В. 1980. Пельтаспермовые птеридоспермы рода Tatarina // Палеонтологический журнал. № 2. С. 116-132].

Mogutcheva, N.K. 1980. Distribution of peltasperms pteridosperms in the Triassic flora of Eastern Taimyr. In: The Paleontology and Stratigraphy of the Triassic of Central Siberia, (A.S. Dagys, ed.), pp. 93-112. Nauka, Novosibirsk (in Russian). [Могучева Н.К. 1980. Распространение пельтаспермовых птеридоспермов в триасовой флоре Восточного Таймыра // Палеонтология и стратиграфия триаса Средней Сибири. Новосибирск: Наука. С. 93-112].

Mogutcheva, N.K. 1984. New Triassic plants of Middle Siberia. In: New species of ancient invertebrates and plants of the oil-and-gas-bearing provinces of Siberia, pp. 50-55, SNIIGGiMS, Novosibirsk (in Russian). [Могучева Н.K. 1984. Новые триасовые растения Средней Сибири // Новые виды Аревних беспозвоночных и растений нефтегазоносных провинций Сибири. Новосибирск: СНИИГГиМС. С. 50-55].

Mogutcheva, N.K. \& V. Krugovykh. 2009. New data on the stratigraphic chart for Triassic deposits in the Tunguska syneclise and Kuznetsk basin. Stratigraphy and Geological Correlation 17(5):510-518.

Neuburg, M.F. 1936. On the stratigraphy of the coal-bearing deposits of the Kuznetsk Basin. Izvestiya Akademii Nank SSSR, Seriya Geologicheskaya 4:469-510 (in Russian). [Нейбург М.Ф. 1936. К стратиграфии угленосных отложений Кузнецкого бассейна / / Известия Академии наук СССР. ОтАеление математических и естественных наук. № 4. С. 469-510]. 
Poort, R.J. \& H. Kerp 1990. Aspects of Permian palaeobotany and palynology. XI. On the recognition of true peltasperms in the Upper Permian of Western and Central Europe and a reclassification of species formerly included in Peltaspermum Harris. Review of Palaeobotany and Palynology 63(3-4):197-225.

Radczenko, G.P. 1936. Some plant remains from the region of the Ostashkiny Gory in the Kuznetsk basin. Materialy po geologii Zapadno-Sibirskogo kraya 1-3(35):1-24 (in Russian). ГаАченко Г.П. 1936. Некоторые растительные остатки из района Осташкиных гор в Кузнецком бассейне // Материалы по геологии Западно-Сибирского края. Томск. Т. 35. С. 1-24].

Radczenko, G.P. 1973. Altay-Sayany folded area. In: Stratigraphy of the USSR. The Triassic system, (L.D. Kiparisova, G.P. Radczenko \& V. P. Gorsky, eds.), pp. 223-232, Nedra, Moscow (in Russian). Рацченко Г.П. 1973. А^таеСаянская складчатая область // Стратиграфия СССР. Триасовая система. Москва: НеАра. С. 223-232].

Radczenko, G.P. \& I.N. Srebrodolskaya 1960. New species of the gymnosperms of Siberia and Kazakhstan. In: New genera and species of ancient plants and invertebrates of the USSR. Part 1, (B.P. Markovsky, ed.), pp. 117-122, Gosgeoltekhizdat, Moscow (in Russian). [Радченко Г.П., Cpeбродольская И.Н. 1960. Новые виды голосеменных Сибири и Казахстана / / Новые роды и виды древних растений и беспозвоночных СССР. Ч. 1. Москва: Госгеолтехиздат. С. 117-122].

Sadovnikov, G.N. 1981. Regional stratigraphic subdivisions of the Upper Permian and Lower Triassic of the Siberian platform and adjoining regions. Sovetskay Geologiya 1: 74 84 (in Russian). [Садовников Г.Н. 1981. Региональные стратиграфические подразделения верхней перми и нижнего триаса Сибирской платформы и сопредельных районов // Советская геология. № 1. С. 74-84].

Schimper, W.P. 1869. Traité de paléontologie végétale ou la flore $d u$ monde primitif dans ses raports avec les formations géologiques et la flore du monde actuel. J. B. Bailliere et Fils, Paris, 896 pp.

Srebrodolskaya, I.N. 1960. The new Early Triassic species of Rhipidopsis. In: New genera and species of ancient plants and invertebrates of the USSR. Part 1, (B.P. Markovsky, ed.), pp. 107-108. Gosgeoltekhizdat, Moscow (in Russian). [Сребродольская И.Н. 1960. Новый раннетриасовый сибирский рипидопсис // Новые роды и виды древних растений и беспозвоночных СССР. Ч. 1. Москва: Госгеолтехиздат. С. 107-108].

Townrow, J.A. 1960. The Peltaspermaceae, a pteridosperm family of Permian and Triassic age. Palaeontology 3: 333-361.

Vladimirovich, V.P. 1967. Biostratigraphy of Triassic and Jurassic continental deposits of eastern slope of the Urals, northern Kazakhstan and mountain part of western Siberia. In: Stratigraphy and paleontology of Mesozoic and Paleogene-Neogene continental deposits of the Asiatic part of the USSR, (G.G. Martinson, ed.), pp. 46-55. Nauka, Leningrad (in Russian). [ВАадимирович В.П. 1967. Биостратиграфия континентальных триасовых и юрских отложений восточного склона Урала, Северного Казахстана и горной части ЗапаАной Сибири // Стратиграфия и палеонтология мезозойских и палеоген-неогеновых отложений азиатской части СССР. Аенинград: Наука. С. 46-55].

Vladimirovich, V.P. 1980. Early Triassic ferns of Western Siberia (Kuznetsk Basin). Ezhegodnik V sesoyuznogo Paleontologicheskogo Obshchestva 23:265-285 (in Russian). [ВАаАимирович В.П. 1980. Раннетриасовые папоротники 3ападной Сибири (Кузнецкий бассейн) // Ежегодник Всесоюзн. палеонтол. общ. Т. 23. С. 265-285].

Vladimirovich, V. P. 1981. Ferns of the Early Triassic of the Western Siberia. Ezhegodnik V sesoyuznogo Paleontologicheskogo Obshchestva 24: 215-226 (in Russian). [ВАадимирович В.П. 1981. Папоротники раннего триаса Западной Сибири // Ежегодник Всесоюзн. палеонтол. общ. T. 24. C. 215-226].

Vladimirovich, V.P., V.M. Lebedev, Y.N. Popov, G.P. Radczenko \& N.A. Shvedov 1967. Stratigraphy of Triassic deposits of the Middle Siberia. In: Stratigraphy of Mesozoic and Palaeozoic of the Middle Siberia, pp. 7-30, Nauka, Novosibirsk (in Russian). [ВАадимирович В.П., Аебедев В.М., Попов Ю.Н., Радченко Г.П., Шведов Н.А. 1967. Стратиграфия триасовых отложений Средней Сибири / / Стратиграфия мезозоя и кайнозоя Средней Сибири. Новосибирск: Наука. С. 7-30].

Zhang, Y., S. Zheng \& S.V. Naugolnykh 2012. A new species of Lepidopteris discovered from the Upper Permian of China with its stratigraphic and biologic implications. Chinese Science Bulletin 57(27):3603-3609. 